\title{
Extract of Yellow Root (Arcangelisia Flava (L.) Merr.) from Several Regions in Kalimantan: Alkaloid Content and Cytotoxicity towards WiDr Colorectal Cancer Cells
}

\author{
Roihatul Mutiah ${ }^{1}$, Farenza Okta Kirana ${ }^{1}$, Rahmi Annisa ${ }^{1}$, Ana Rahmawati ${ }^{2}$, Ferry Sandra ${ }^{3 *}$ \\ ${ }^{1}$ Department of Pharmacy, Faculty of Medical and Health Sciences, Maulana Malik Ibrahim State Islamic University of \\ Malang, Indonesia \\ ${ }^{2}$ Department of Medical Education, Faculty of Medical and Health Sciences, Maulana Malik Ibrahim State Islamic \\ University of Malang, Indonesia
}

${ }^{3}$ Department of Biochemistry and Molecular Biology, Division of Oral Biology, Faculty of Dentistry, Universitas Trisakti, Jl. Kyai Tapa No.260, Jakarta, Indonesia

\begin{abstract}
Yellow root (Arcangelisia flava (L.) Merr.) has been scientifically known to have potential as an antimalarial, antibacterial, antioxidant, and anticancer. The purpose of this study was to determine the profile of alkaloid content and cytotoxicity of yellow root extract from several regions in Kalimantan. The alkaloid content was tested using the thin layer chromatography (TLC) method with dragendorf reagent. Cytotoxic in vitro test was conducted against WiDr colorectal cancer cells using the 3-(4,5-dimethylthiazol-2-il)-2,5diphenyltetrazolium bromide (MTT) assay. Yellow roots were collected from Samarinda city, Banjarmasin city, Barito Timur regency, Malinau district, and Balikpapan City. The MTT inhibitory concentration $50\left(\mathrm{IC}_{50}\right)$ of yellow root extracts were $573.308 \mu \mathrm{g} / \mathrm{mL} ; 582.857$ $\mu \mathrm{g} / \mathrm{mL} ; 296.326 \mu \mathrm{g} / \mathrm{mL} ; 114.119 \mu \mathrm{g} / \mathrm{mL}$; and $320.162 \mu \mathrm{g} / \mathrm{mL}$ respectively. Results of the compound identification indicated that alkaloid was found in $A$. flava from all regions. Alkaloids of $A$. flava extract should be investigated further in order to find possible active agent that could decrease the viability of WiDr colorectal cancer cells.
\end{abstract}

Keywords: Arcangelisia flava, Borneo, colorectal cancer, Kalimantan, WiDr cells

\section{INTRODUCTION}

Cancer is a disease caused by abnormal cells, that have high proliferation (Sandra, 2004), anti-apoptosis (Hendarmin, et al., 2018), survival ability (Sandra, 2018), and migration (Vallianou, et al., 2015) or commonly known as metastasize to other body parts. One of the many cancers suffered is colorectal cancer. Colorectal cancer is one type of cancer that occurs in the colon mucosa where the disease has a high morbidity and mortality rate (Tatuhey, et al., 2014).

Colorectal cancer ranks third as a type of cancer that often occurs and ranks fourth as the leading cause of this disease in the world (Bray, et al., 2018). Colorectal cancer is the third cause of

Submitted: August 1, 2019

Revised: July 12, 2020

Accepted: July 13, 2020 
death in men and women in the United States (Kim, et al., 2018). According to the American Cancer Society, this cancer is one of the most malignant diseases in the world and ranks third in a condition that is often diagnosed in the United States and fourth in Asia (Rahmadania, et al., 2016).

Yellow root (Arcangelisia flava (L.) Merr.) is a plant from the Menispermaceae family. A. flava is a liana plant with a length of up to 20 meters (Widyatmoko, et al., 1998). A. flava can grow well on flat, dry, non-muddy soil, and many contain humus, with rainfall of 2000-3000 mm per year (Heyne, 1987). Dayak people in Kalimantan or previously known as Borneo, use A. flava to treat hepatitis, fever, infections, digestive disorders, intestinal worms, and cancer sores (Pratama, 2016). Some studies show that A. flava is useful as an antimalarial (Lovin, et al., 2012), antibacterial, antioxidant (Maryani, et al., 2013), and anticancer (Keawpradub, et al., 2005). The active compounds of A. flava are thought to have anticancer activity, including alkaloids like berberine, palmatine, and jatrorrhizine. (Pratama, 2016).

The content of each plant has different activities. This difference can be caused by internal factors such as hormones, water and genetic balance, as well as external factors such as area height, rainfall, soil type, climate, temperature, reaction soil, gas composition in the ground, and soil nutrient availability (Mpapa, 2016). There present study was conducted to determine the content and cytotoxicity of $A$. flava plants from several regions in Kalimantan.

\section{MATERIALS AND METHODS}

\section{Extraction}

A. flava stems were obtained from Samarinda city (AfSR), Banjarmasin city (AfBM), Barito Timur regency (AfBT), Malinau district (AfMN), and Balikpapan city (AfBP) (Figure 1). A. flava stems were determinated at the Indonesian Institute of Sciences/Lembaga Ilmu Pengetahuan Indonesia (LIPI) Purwodadi (certificate No.0402/ IPH.06/HM/IV/2019). Extraction of A. flava stems were performed using maceration method with Ultrasound-Assisted Extraction (UAE) and 80\% ethanol (Merck, Darmstadt, Germany) as solvent. Five grams of each dry powder sample were dissolved with $100 \mathrm{~mL}$ of solvent. Extraction was conducted for 2 minutes with three repetitions. The extract was filtered, and the filtrate was heated at $40^{\circ} \mathrm{C}$.

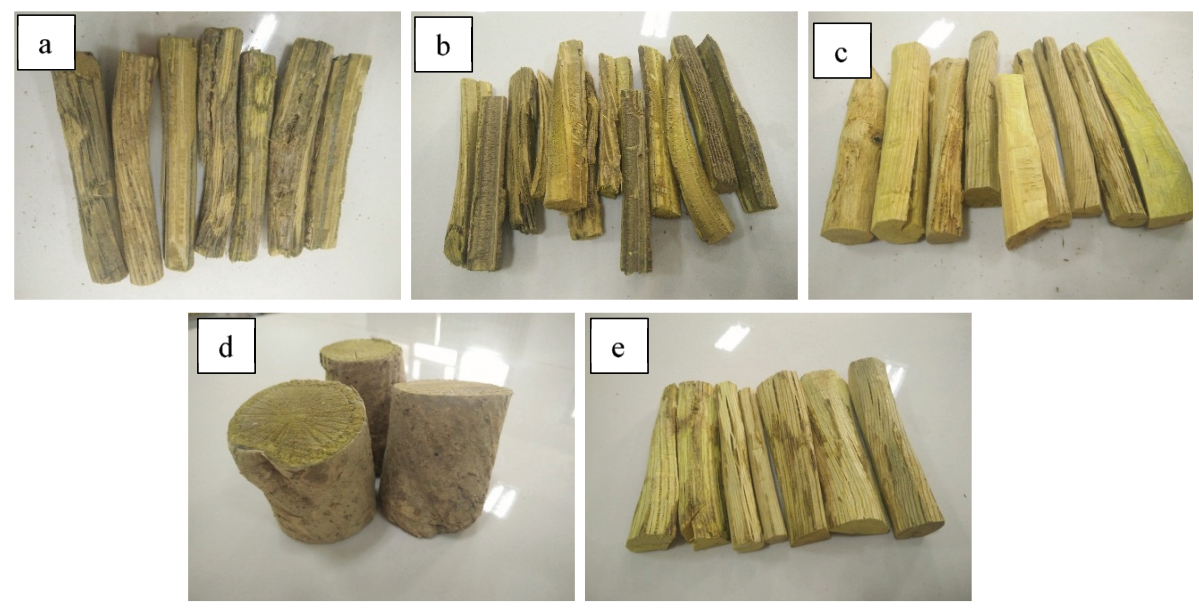

Figure 1. Samples A. flava from (a) AfSR, (b) AfBM, (c) AfBT, (d) AfMN, (e) AfBP. 


\section{Phytochemical Test of Alkaloid}

Phytochemical tests were conducted using thin layer chromatography (TLC) method. The stationary phase used was silica gel GF254 plate and the mobile phase were chloroform and methanol (2:3). To get stain appearance, the dragendorf reagent was used. Samples that produced orange stains after spraying the dragendorf reagent indicated an alkaloid compound (Minarno, 2015).

\section{Preparation of Sample}

Stock solutions made by extracting $A$. flava as much as $10 \mathrm{mg}$ and dissolved with $1 \%$ dimethyl sulfoxide (DMSO) as much as $100 \mu \mathrm{L}$. Then dilution was done using Roswell Park Memorial Institute (RPMI) medium (Gibco, Invitrogen cell culture, Carisbad, USA). The concentrations were $500,250,125,62.5$ and $31.25 \mu \mathrm{g} / \mathrm{mL}$. These solutions were used in the WiDr cell cytotoxic test. As the positive control, doxorubicin was used in the concentration of $100,50,25,12.5$ and $6.25 \mu \mathrm{g} / \mathrm{mL}$.

\section{Cytotoxic Test towards WiDr Cells}

The cytotoxic tests were conducted in the Laboratory of Parasitology, Faculty of Medicine, Universitas Gadjah Mada, Yogyakarta. WiDr cells were cultured with RPMI medium, then harvested. The cells were transferred into a 96-well plate (Iwaki, Kuala Lumpur, Malaysia) with a total of $30 \times 10^{4}$ cells/well followed by $24 \mathrm{~h}$ incubated in an incubator with $\mathrm{CO}_{2}$. Cells were treated with tested solution as indicated concentrations. The final volume was $100 \mu \mathrm{L} /$ well. Cells were incubated for $24 \mathrm{~h}$. Positive controls group were treated with doxorubicin (OBG Sanbe $2 \mathrm{mg} / \mathrm{mL}$ ). Then the cells were added with an MTT reagent (Sigma, St Louis USA) and incubated for $2 \mathrm{~h}$. Then wells were added with $10 \%$ sodium dodecyl sulphate (SDS) (Sigma) in $0.1 \mathrm{~N} \mathrm{HCl}$ (Merck) as much as $100 \mu \mathrm{L}$, then wrapped and incubated for $24 \mathrm{~h}$. This stopper solution served to dissolve formazan crystals. Next, the absorbances of solutions were read using an microplate reader (Bio-rad, Hercules, California, USA) with a wavelength of 550-600 nm.

The absorbance values were calculated to obtain the viability percentage of viable cells. Then the percentages were used to find inhibitory concentration $50\left(\mathrm{IC}_{50}\right)$ value. The $\mathrm{IC}_{50}<50 \mu \mathrm{g} /$ $\mathrm{mL}$ was categorized as having a strong cytotoxic effect, $50 \mu \mathrm{g} / \mathrm{mL}<\mathrm{IC}_{50}<200 \mu \mathrm{g} / \mathrm{mL}$ was categorized as having a moderate cytotoxic effect, $200 \mu \mathrm{g} /$ $\mathrm{mL}<\mathrm{IC}_{50}<1000 \mu \mathrm{g} / \mathrm{mL}$ was categorized as having a weak cytotoxic effect, and $\mathrm{IC}_{50}>1000 \mu \mathrm{g} / \mathrm{mL}$ was categorized as having no cytotoxic effect (Kuete, 2017). The $\mathrm{IC}_{50}$ value was analyzed by using probit in regression of SPSS version 24 (IBM Corp., Armonk, New York, USA) $\mathrm{IC}_{50}$ values were analyzed based on a percent of the viability of viable cells/replication with replication three times.

\section{RESULTS}

\section{TLC Results of $A$. flava Extracts}

The results of the phytochemical test were identified by using TLC (Figure 2). Figure 2 shows an orange stain after being given dragendorf reagent. All A. flava samples produced orange stains indicating that all samples contained alkaloid compounds. The $\mathrm{Rf}$ values of TLC results were shown in Table 1. All AfSR, AfBM, AfBT, AfMN and AfBP extracts had almost similar Rf values.

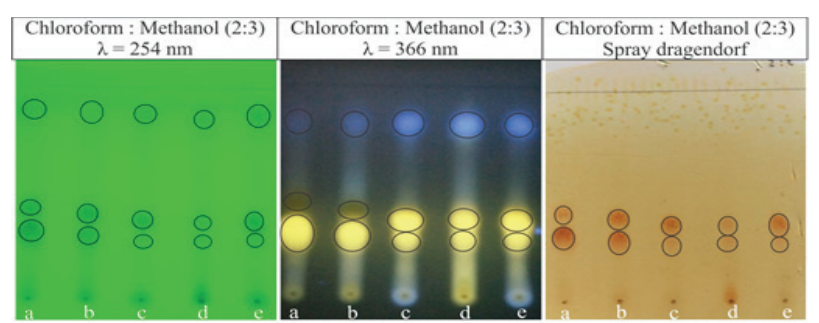

Figure 2. TLC results of (a) AfSR, (b) AfBM, (c) AfBT, (d) AfMN, (e) AfBP extracts. 
Table 1. TLC Results of $A$. flava with mobile phase Chloroform : Methanol (2:3), stationary phase Silica gel GF254.

\begin{tabular}{clcccc}
\hline \multirow{2}{*}{ No } & \multirow{2}{*}{ Sample Name } & \multicolumn{2}{c}{ Rf value } & \multirow{2}{*}{$\begin{array}{c}\text { Stain } \\
\text { Color }\end{array}$} & Compound \\
\cline { 3 - 4 } & & $\mathbf{I}$ & $\mathbf{2}$ & & \\
\hline I & AfSR & 0.36 & 0.46 & Orange & Alkaloid \\
2 & AfBM & 0.34 & 0.2 & Orange & Alkaloid \\
3 & AfBT & 0.32 & 0.4 & Orange & Alkaloid \\
4 & AfMN & 0.32 & 0.4 & Orange & Alkaloid \\
5 & AfBP & 0.32 & 0.4 & Orange & Alkaloid \\
\hline
\end{tabular}

The absorbance values of MTT were converted to the percentage of viable cells. (Figure 3 and 4). All AfSR, AfBM, AfBT, AfMN and AfBP extracts decreased the percentage of viable WiDr cells in dose-dependent manners (Figure 3). AfMN extract had the highest capacity in decreasing the percentage of viable WiDr cells. Compared with AfSR, AfBM, AfBT and AfBP extracts, the $125 \mu \mathrm{g} /$ $\mathrm{mL}$ and $250 \mu \mathrm{g} / \mathrm{mL}$ AfMN extracts markedly de- creased the percentage of viable WiDr cells. Results of doxorubicin as the positive control in this study showed a clear decrease of the percentage of viable WiDr cells in a dose-dependent manner (Figure 4). Among all investigated $A$. flava extracts, AfMN extract had the highest cytotoxic effect with the $\mathrm{IC}_{50}$ of $114.119 \pm 6.617 \mu \mathrm{g} / \mathrm{mL}$ and category of cytotoxic effect was moderate (Table 2).

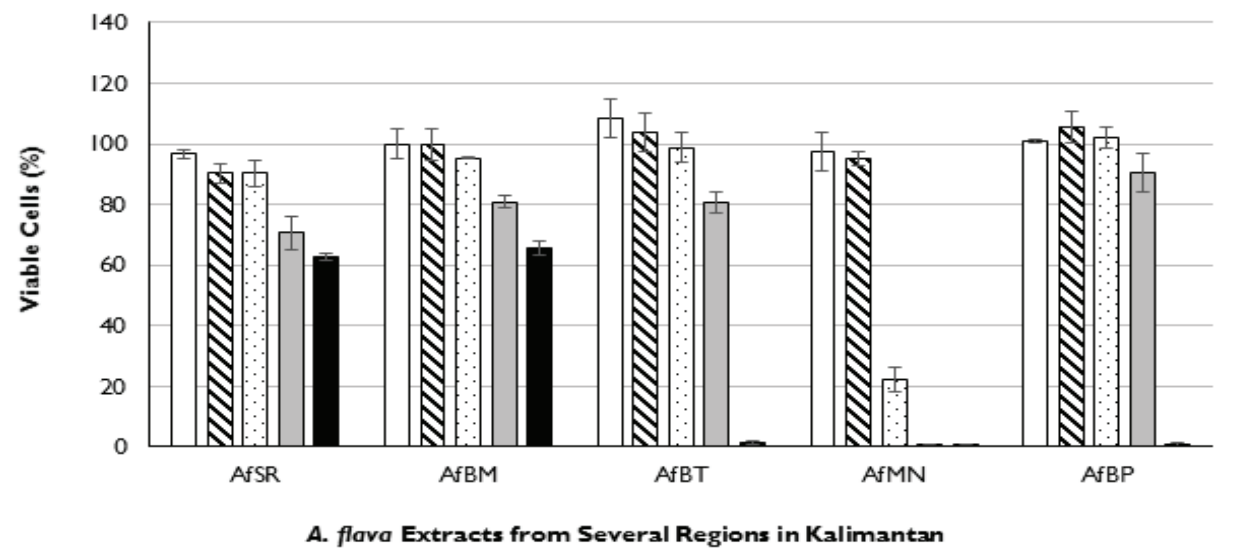

Figure 3. Effect of $A$. flava extract from several regions in Kalimantan towards viability of WiDr cells. Blank bar: $31.25 \mu \mathrm{g} / \mathrm{mL}$, striped bar: $62.5 \mu \mathrm{g} / \mathrm{mL}$, dotted bar: $125 \mu \mathrm{g} / \mathrm{mL}$, grey bar: $250 \mu \mathrm{g} / \mathrm{mL}$, black bar: $500 \mu \mathrm{g} / \mathrm{mL}$.

\section{DISCUSSION}

Based on the present results shown in Figure 2 and Table 1, all samples had 2 orange stains with almost similar Rf values and color intensity, marked as alkaloids. Alkaloid compounds have been reported to inhibit cell growth by blocking the G1 phase of the cell cycle (Arung, et al., 2010; Widowati, et al., 2010). Berberine, one of the al- kaloid compounds could bind with DNA and RNA and induce DNA damage in cancer cells by regulating the activity of DNA topoisomerase (Wang, et al., 2016).

Among all tested extracts, the AfMN extract whose stem from the Malinau district had the highest cytotoxicity. These results strengthen current knowledge of plant variation. The variation can be caused by internal and external factors 


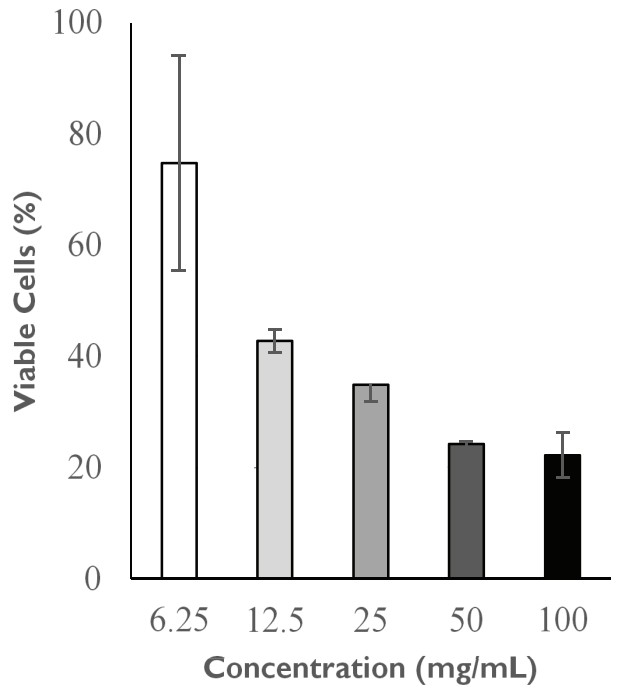

Figure 4. Effect of doxorubicin towards viability of WiDr cells.

(Mpapa, 2016). Therefore, research and utilization of medicinal plants should carefully consider the source of the plants. $\mathrm{IC}_{50}$ of AfMN extract was $114.119 \pm 6.617 \mu \mathrm{g} / \mathrm{mL}$ and categorized as moderate. Although AfMN extract was not as strong as doxorubicin in inducing cytotoxicity of WiDr colorectal cancer cells, it could have a potential active alkaloid compound, therefore AfMN extract should be investigated further.

Table 2. $\mathrm{IC}_{50}$ values of doxorubicin, AfSR, AfBM, AfBT, AfMN and AfBP extracts towards WiDr cells. Data were obtained from 3 replications.

\begin{tabular}{ccc}
\hline Treatments & IC $_{50} \pm \mathbf{S D}(\mathbf{m g} / \mathbf{m L})$ & Cytotoxic Effect \\
\hline Doxorubicin & $45.90 I \pm 15.95 I$ & Strong \\
AfSR & $573.308 \pm 33.631$ & Weak \\
AfBM & $582.857 \pm 12.843$ & Weak \\
AfBT & $296.326 \pm 14.129$ & Weak \\
AfMN & $114.119 \pm 6.617$ & Moderate \\
AfBP & $320.162 \pm 12.188$ & Weak \\
\hline
\end{tabular}

SD: Standard deviation

In present study, cytotoxic study with MTT assay was performed. Treated viable WiDr colorectal cancer cells were measured with colorimetry using microplate reader. Lower percentage of viable cells could be considered as inhibition of cell growth/proliferation as well as induction of apoptosis (Sandra, et al., 2017). Therefore, further study should be conducted with different assays to ensure the mechanism of the A. flava stem extract, whether inhibiting cell growth/proliferation, inducing of apoptosis or both at the same time (Sandra, et al., 2017).

\section{CONCLUSION}

Alkaloid content of A. flava stem extract could be potential in decreasing viability of WiDr colorectal cancer cells. Further research should be explored on active agent in the alkaloids, especially alkaloids of the AfMN extract.

\section{REFERENCES}

Arung, E.T., Wicaksono, B.D., Handoko, Y.A., Kusuma, I.W., Shimizu, K., Yulia, D., et al., 2010, Cytotoxic effect of artocarpin on T47D cells, J. Nat. Med., 64(4), 423-429.

Bray, F., Ferlay, J., Soerjomataram, I., Siegel, R.L., Torre, L.A. and Jemal, A., 2018, Global Cancer Statistics 2018: GLOBOCAN Estimates of Incidence and Mortality Worldwide for 36 Cancers in 185 Countries, C.A. Cancer J. Clin., 68, 394424.

Hendarmin, L., Kawano, S., Yoshiga, D., Sandra, F., Mitsuyasu, T., Nakao, Y., et al., 2008, An Anti-apoptotic Role of NF-KB in TNFa-induced Apoptosis in an Ameloblastoma Cell Line, Oral Sci. Int., 5, 96-103.

Heyne, K., 1987, Tumbuhan Berguna Indonesia, Volume 4, Jakarta: Yayasan Sarana Wana Jaya.

Keawpradub, N., Dej-adisai, S. and Yuenyongsawad, S., 2005, Antioxidant and cytotoxic activities of Thai medicinal plants named Khaminkhruea: Arcangelisia flava, Coscinium blumeanum and Fibraurea tinctoria, Songklanakarin J. Sci. Technol., 27(Suppl. 2), 455-467.

Kim, T. and Croce, C.M., 2018, Long noncoding RNAs: Undeciphered Cellular Codes Encrypting Keys of Colorectal Cancer Pathogenesis, Cancer Lett., 417, 89-95. 
Lovin, E.R., Arwati, H. and Ramadhani R.B., 2012, In vitro Intraerythrocytic Antimalaria Activity of Akar Kuning (Arcangelisia flava (L) Merr) Stem Aqueous Extract in Plasmodium falciparum, Folia Medica Indonesiana, 48(3), 90-95.

Maryani, Marsoedi, Nusryam, H. and Maftuch, 2013, The Phytochemistry and The Anti-bacterial Activity of Yellow Root (Arcangelisia flava Merr.) Against Aeromonas hydrophyla, J. Bio. Life Sci., 4(2), 180-190.

Minarno, E.B., 2015, Skrining Fitokimia dan Kandungan Total Flavanoid Pada Buah Carica pubescens Lenne \& K. Koch di Kawasan Bromo, Cangar, Dan Dataran Tinggi Dieng, El-Hayah, 5(2), 73-82.

Mpapa, B.L., 2016, Analisis Kesuburan Tanah Tempat Tumbuh Pohon Jati (Tectona grandis L.) pada Ketinggian yang Berbeda, Jurnal Agrista, 20(3), 135-139.

Pratama, M.R.F., 2016, Akar Kuning (Arcangelisia flava) Sebagai Inhibitor EGFR: Kajian in silico, Farmagazine, 3(1), 6-17.

Rahmadania, E., Wibowo, A.A. and Rosida, L., 2016, Distribusi Pola Diet Pasien Kanker Kolorektal Di RSUD Ulin Banjarmasin Periode Agustus-Oktober 2015, Berkala Kedokteran, 12(2), 215-227.

Sandra, F., Harada, H., Nakamura, N. and Ohishi, M., 2004, Midkine induced growth of ameloblastoma through MAPK and Akt pathways, Oral Oncol., 40(3), 274-280.

Sandra, F. and Rita Lahirin, R., 2017, Human Umbilical Cord Blood Serum Has Higher Potential in Inducing Proliferation of Fibroblast than Fetal Bo- vine Serum, Mol. Cell. Biomed. Sci., 1(2), 65-69. Sandra, F. and Sidharta, M.A., 2017, Caffeic Acid Induced Apoptosis in MG63 Osteosarcoma Cells Through Activation of Caspases, Mol. Cell. Biomed. Sci., 1(1), 28-33.

Sandra, F., 2018, Survivin Ser81 Plays An Important Role in PI3K/Akt/mTOR Signaling Pathway, Mol. Cell. Biomed. Sci., 2(2), 55-59.

Tatuhey, W.S., Nikijuluw, H. and Mainase, J., 2014, Karakteristik Kanker Kolorektal Di RSUD Dr. M Haulussy Ambon Periode Januari 2012-Juni 2013, Molucca Medica, 4(2), 150-157.

Vallianou, N.G., Evangelopoulos, A., Schizas, N. and Kazazis, C., 2015, Potential anticancer properties and mechanisms of action of curcumin, Anticancer Res., 35(2), 645-651.

Wang, K., Zhang, C., Bao, J., Jia, X., Liang, Y., Wang, X., et al., 2016, Synergistic Chemopreventive Effect of Curcumin and Berberine on Human Breast Cancer Cell Through Induction of Apoptosis and Autophagic Cell Death, Sci. Rep., 6, 1-14.

Widowati, W., Mozef, T., Risdian, C., Ratnawati, H., Tjahyani, S. and Sandra, F., 2010, Apoptosis and Antioxidant Activities of Catharanthus rosues [L] G.Don Extract on Breast Cancer Cell Line, Indones. J. Cancer Chemoprevent., 1(2), 99-107. Widyatmoko, D. and Zick., F., 1998, The Flora of Bukit Tiga Puluh National Park, Kerumutan Sanctuary and Mahato Protective Reserve, Riau, Indonesia. Bogor: Indonesian Botanical Gardens in collaboration with Yayasan Sosial Chevron dan Texaco Indonesia. 